\title{
EFFECTS OF MARKET VARIABLES ON NET INCORPORATION: EVIDENCE FROM TURKISH 2018 DEBT AND EXCHANGE RATE CRISIS
}

\author{
DOI: 10.17261/Pressacademia.2020.1317 \\ JBEF- V.9-ISS.4-2020(8)-p.373-385
}

\section{Mehmet Kuzu}

Bayburt Universty, Department of Business Administration, Bayburt, Turkey. mehmetkuzu86@gmail.com, ORCID: 0000-0001-5354-4368

Date Received: October 5, 2020

Date Accepted: December 12, 2020

To cite this document

Kuzu, M., (2020). Effects of market variables on net incorporation: evidence from Turkish 2018 debt and exchange rate crises. Journal of Business, Economics and Finance (JBEF), V.9(4), p.373-385.

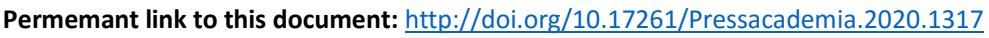

Copyright: Published by PressAcademia and limited licenced re-use rights only.

\begin{abstract}
Purpose- The aim of this study is to determine the periodic effects of market variables on net incorporation during the Turkish 2018 Currency and Debt Crisis in Turkey. Because one of the main problems of the companies in Turkey are higher foreign exchange position. Increased exchange rate, interest rate and inflation shocks increases the fragility of the economy of Turkey. High foreign exchange openings together with the increasing fragility increase the risk of closing on companies. On the other hand, increasing interest shocks increase financing costs and increase the risk of closure, and make it difficult for new companies to open up. Therefore, to create a perspective for the study was selected the 2018 Turkey exchange rate and debt crisis as a case.

Methodology- In this essay concept of firm had been used as company or corporate mean. And also concept of firming or net incorporation had been used difference between number of new opening companies and number of closing companies. Exchange rate, interest rate and inflation were selected as market variables. Closing firms and opening firms were selected as firm variables. The model was formed based on the Vector Auto Regressive Model. The values of the variables were observed in the monthly frequency and in the range of 20101 st month and 201912 th month.

Findings- According to results, inflation and interest had a negative impact on the number of opening firms. And also, the increasing effect of exchange rates on the number of closing firms was generally greater than interest rate and inflation.

Conclusion- Consequently, it has been argued that net firm number growth has been increasing in Turkey during periods when exchange rates are stable in a certain band range and inflation and interest rates start to decrease at the same time.
\end{abstract}

Keywords: Firm Closure, incorporation, Financial Fragility, Exchange and Debt Crises

JEL Codes: G00, G17, G32

\section{INTRODUCTION}

The increase in the number of companies closed and changes in the number of newly opened companies are particularly important in times of crisis. Because every firm that closes in these periods is more panic and higher risk premium pricing for the country in crisis.

For this reason, the effects of market variables on firms' closing and new opening are analyzed in terms of crisis periods. Economic crises cause many companies to close and a decrease in the number of new companies. In this context, the 2018 crisis should be examined first.

After the 2001 banking crisis, a policy framework of low exchange rate and high interest rates has begun to implement in the Turkish economy. In the following years, the abundance of global liquidity has helped that the Turkish economy achieve sustainable high growth rates. The financial crisis that emerged in the sub-threshold credit market in 2007 turned into a global crisis with the bankruptcy of Lehman Brothers in September 2008. 
While Turkey recovered rapidly during the 2008 global crisis, it reached an effective average growth rate of about $7 \%$. The relative decline in the public debt ratio the 2010's has reduced the strong its' growth rates reached in the 2000's (Eliot, 2018). The recession and commercial-financial losses caused by the global crisis negatively affected to markets. Interest rate and exchange rate shocks caused financial fragility in emerging markets after FED Chairman Bernanke had announced a gradual reduction of the bond-buying program on May 22, 2013.

As a result of these fragility, the economic policy framework of the Turkish economy has evolved into the policy framework of high exchange rates-high interest rates- high inflation. Rising political risk and the starting of Fed's interest rate in 2016 have increased exchange rate shocks in the Turkish economy. With the structuring of exchange rate shocks and increasing external financing deficits, the macro-financial equilibration mechanism has deteriorated.

Turkish lira has been begun depreciating with the increasing rate since February 2018. As political uncertainties make financial markets more volatile, aside from the global factors, June 24, 2018 elections can be stated as the main reason for this significant fluctuation in the price of the Turkish lira. One month before elections, May 2018, percentage increase so the amount of depreciation in lira per dollar rate is the 7.3 percent, that is the highest level relative to percentage changes in other countries' exchange rates (Kerra Geldi, 2018:4)

The diplomatic crisis between the US and Turkey gave a push to the economic downturn in Turkey that was already coming. Indeed, the Turkish Lira already depreciated by more than 20\% against USD in 2018 before the diplomatic tension peaked. The depreciation in the Turkish Lira against USD for 2018 was roughly 41\% (Oyvat, 2018)

After the shock wave in the exchange rate, the Turkish government tried to stabilize the exchange rates with the regulations it made in terms of the management of financial crises. On the other hand, it has taken a number of measures for companies facing the risk of closure and bankruptcy. In addition, The government has tried to transform the direction of the political economy of the country from the low exchange rate-high interest policy framework to an exporter economy.

Commercial and financial losses arising during financial crisis periods increase the risk on the equity of companies. After this risk, businesses whose asset-resource match is broken or that lose their equity are faced with the risk of bankruptcy and closure.

Increasing exchange rates in times of crisis can negatively affect companies in two fundamental ways. The first is foreign currency openings. Another is that enterprises that produce with imported inputs lose their domestic goods competitive power. On the other hand, exchange rate shocks will make it difficult for companies to access financing in terms of external resources during the investment period for new companies.

Increasing interest rates during crisis periods adversely affect the borrowing dynamics of firms. Disrupted debt dynamics can also cause failure to operate the firm. Increasing financing costs with increasing interest rates increase the sales price of the enterprises and cause a loss of competitiveness. On the other hand, high interest rates will make it difficult for new companies to access financing during the investment period.

Increasing inflation rates during crisis periods adversely affect the competitiveness of firms. On the other hand, low competitive power will cause low profitability, so weak profit expectations may not be attractive for new companies to enter the sector.

The most common crisis dynamics in emerging market economies is increasing financial vulnerabilities. Exchange rate, interest rate and inflation shocks are the basis of these vulnerabilities. For this reason, the effects of the crisis on the number of firms that are closed and the number of new firms to be opened have been tried to be analyzed over the variables of exchange rate, interest rate and inflation during the crisis period.

Theoretically, this process is likely to have negative effects on the number of opening and closing companies in Turkey for each of them. Because one of the main problems of many companies in Turkey is the increased risk of bankruptcy due to high foreign exchange position deficits in real sector. On the other hand, the commercial losses caused by the low competitiveness of the outward-facing firms also increased these risks. The increasing number of firms that are closing and the decreasing number of firms that are opening as a result of these risks caused the transformation of economic crises into financial crises.

\section{LITERATURE REVIEW}

The relevant literature can be examined within the framework of two basic problematics of the research. The first of these is the factors affecting incorporation, and another is the 2018 Turkish exchange rate crisis. Ertaş and Çetin, (2009) studied the relationship between incorporation and macroeconomic variables in Turkey between 1995-2008 with granger causality analysis method. In the measurement of incorporation, the number of companies opening and closing and their size were used. According 
to the findings, it was determined that the incorporation interacts with GDP, real wages, real exchange rate, ISE Index, CPI, export and import variables.

Bakış and Kökkızıl, (2017) The general course of companies established and closing in Turkey in the period 2010-2016 and their relationship with macroeconomic indicators were examined. Regression analysis was performed taking into account the annual changes in all macroeconomic indicators and the number of companies established and closing. In econometric analyses, which were conducted by checking the effects of the year, the effect of the increase in the number of firms established on employment and gross domestic product was statistically meaningless; however, the effect of the increase in the number of firms closing on employment and national income was found to be negative and statistically significant.

According to Metzger (2008), financial losses incurred by banks due to firm closure are effective on entrepreneurs starting a new firm, while losses incurred by shareholders and entrepreneurs are not effective.

Egbunike and Okerekeoti (2018) examines that the effects of interest rate, inflation rate, exchange rate and the gross domestic product (GDP) growth rate, with the firm characteristics as framework within size, leverage and liquidity with consumer goods sector on the Nigerian Stock Exchange, by means of multiple linear regression as the method of validating the hypotheses. The study shows that no significant effect for interest rate and exchange rate, but a significant effect for inflation rate and GDP growth rate on ROA. However, the firm characteristics were significant.

Headd, B. (2003) states that New firms were believed to have high closure rates and these closures are believed to be failures, in spite of fact that U.S. Census Bureau data sources illustrate that these assumptions could not be justified. He concludes that a planned exit strategy makes it possible closing a business without excess debt, sold a viable business, or retired from the work.

Aguilar and Posada (2019), examined the factors that determine the closure or jeopardize the continuity of micro and small enterprises (MSEs). They investigated the determinants of failure from the entrepreneur's perspective using a qualitative approach, and five variables emerged. Their findings shows that there are internal and external variables that impact on an enterprise's continuity, which are themselves correlated.

Coleman etc.(2013), They distinguished between voluntary firm closure in the form of merger or acquisition and compulsory firm closure in the form of failure/permanently closed operations. They underestimated survival rates. In addition, they reach the conclusion of factors that characterize closed businesses were different from those that characterize businesses that had been sold or merged with other businesses.

\subsection{Drivers Leading to Firm Closure}

The closing of existing companies and opening of new companies can be examined within the framework of five concepts. These are the concepts of mission, vision, internal environment, external environment and company purpose. The goal of firms is to maximize the present value of shareholders' wealth. Failure to fulfill this condition causes companies to fail to reach their vision and fulfill their mission. In this process, the rate of closing down and opening new companies decreases.

The closure of companies is generally divided into two. These; It is the company closing at its own will and closing it out against its own will. Closing voluntarily takes place in the form of merging with another company, ending its legal existence or transforming into a non-profit organization.

Closure involuntarily occurs as a result of the company's financial failure or inability to fulfill legal requirements. the factors that stand out for companies to shut down; macroeconomic conditions, low profit expectations, problem of access to resources and lack of competitiveness. Basically, all other factors are related to macroeconomic conditions. The most prominent of these factors are macroeconomic conditions.

The macroeconomic external environment plays an important role in the financial success of businesses. The two most prominent factors in terms of macroeconomic conditions are financial stability and sustainable high growth performance. Financial instability can most often push firms toward financial failure, bankruptcy and closure when companies have basic structural financial problems. Among these structural problems, the most related to financial stability are high foreign exchange position deficits. In such a structure, rising exchange rates will have an effect on the firm's asset-resource balance. On the other hand, low exchange rates will decrease profitability for exporting companies.

For firms that import inputs, rising exchange rates will have an inflationary effect on sales goods. High interest rates will increase the amount of financing expenses and weaken the firm's ability to compete in price. On the other hand, high interest rates will narrow the credit possibilities. On the other hand, the high sustainable growth performance in the country of operation will 
positively affect the credit outlook of the country and expand the opportunities of companies to find foreign resources from abroad. Increasing these opportunities will enable companies to have a sustainable borrowing dynamic.

\subsection{Drivers Leading to New Firm Opening}

The possibilities of opening new companies are also related to the concept of company purpose. In this context; The existence of sectors that promise high profitability, new business lines, the growth targets of existing SMEs by transforming them into companies, the desire to provide financing with equity by incorporating the opportunity to go public, the rising profit expectations in the country, the increase in borrowing opportunities with low interest from abroad, high financial stability can trigger the opening of new companies.

\section{DATA AND METHODOLOGY}

In this study, the interaction between firms and Market Variables (exchange rate, interest rate and inflation) will be examined by on VAR model.

Sims (1980), developed the VAR model by opposing the internal-external variable separation, arguing that each variable in an econometric model can affect another variable and that these variables can also be affected by other variables (Sims, 1980: 149). The VAR model not only expresses the one-way relationship between variables, but also explores the forward and backward connections between variables (Kearney and Monadjemi, 1990: 197-217).

In simultaneous equation systems, it is sometimes necessary to make some constraints on the structural model in order to overcome the problem of determination (Darnell, 1990: 114-116). These restrictions pose a number of difficulties for research., On the other hand, VAR models can give dynamic relations without any constraints on the structural model and are therefore often used for time series (Keating, 1990: 453-454).

The multiple time series in question is assumed to be generated by the var(p) model, which has a stable structure. Where $p$ is the delay value. In short, a VAR(p) model with P variables is written as follows (Lütkepohl, 2005).

$y=v+A y t-1+\ldots+A p y t-p+u$

While variance decomposition determines which variable is the most effective on a time series, the Effect-Response functions examine whether this effective variable can be used as a policy tool. Impulse-response functions; is a method that a standard error that will occur in one of the random error terms reflects the impact of the shock on the present and future values of the internal variables. (Özgen ve Güloğlu, 2004:97, Barışık ve Kesikoğlu, 2006:71).

For the purpose of the study; exchange rate, interest rate and inflation were selected as market variables. The exchange rate is the dollar/TL rate; the interest rate is the 2 -year benchmark bond interest rate. And CPI variable is selected as inflation. The time series of number of closing firms and the number of opening firms have been created as about incorporation variables. As the scope of the study was based on the 2018 Turkish exchange rate crisis, the forecast range was set at monthly frequency for the period 2010-2019.

Data on firms from the Union of Chambers and Commodity Exchanges of Turkey Statistics, data on Market Variables investing.com obtained from their databases. In this respect, three different VAR model has been created. All variables were used as logarithmic form.

Firstly, the Augmented Dickey Fuller Unit Root Test (Dickey and Fuller, 1979), appropriate lag length, and tests on the theoretical assumptions of the VAR model were conducted. As a result of the tests, it was concluded that the established models met the relevant assumptions in relate to VAR model. These assumptions; AR root and AR polynomial inverse roots, autocorrelation, normality test expressing the normal distribution of residuals of time series and variance Heteroskedasticity test were performed. The model is stationary, there is no autocorrelation problem. In addition, the problem of normal distribution and variance was not observed.In order to determine the interaction between variables after long-and short-term equilibrium analysis, the VAR model was established within the framework of the unit root test results for the first difference values of the time series (Brooks, 2014). 
Figure 1: Invers Roots of AR Characteristic Polynomial

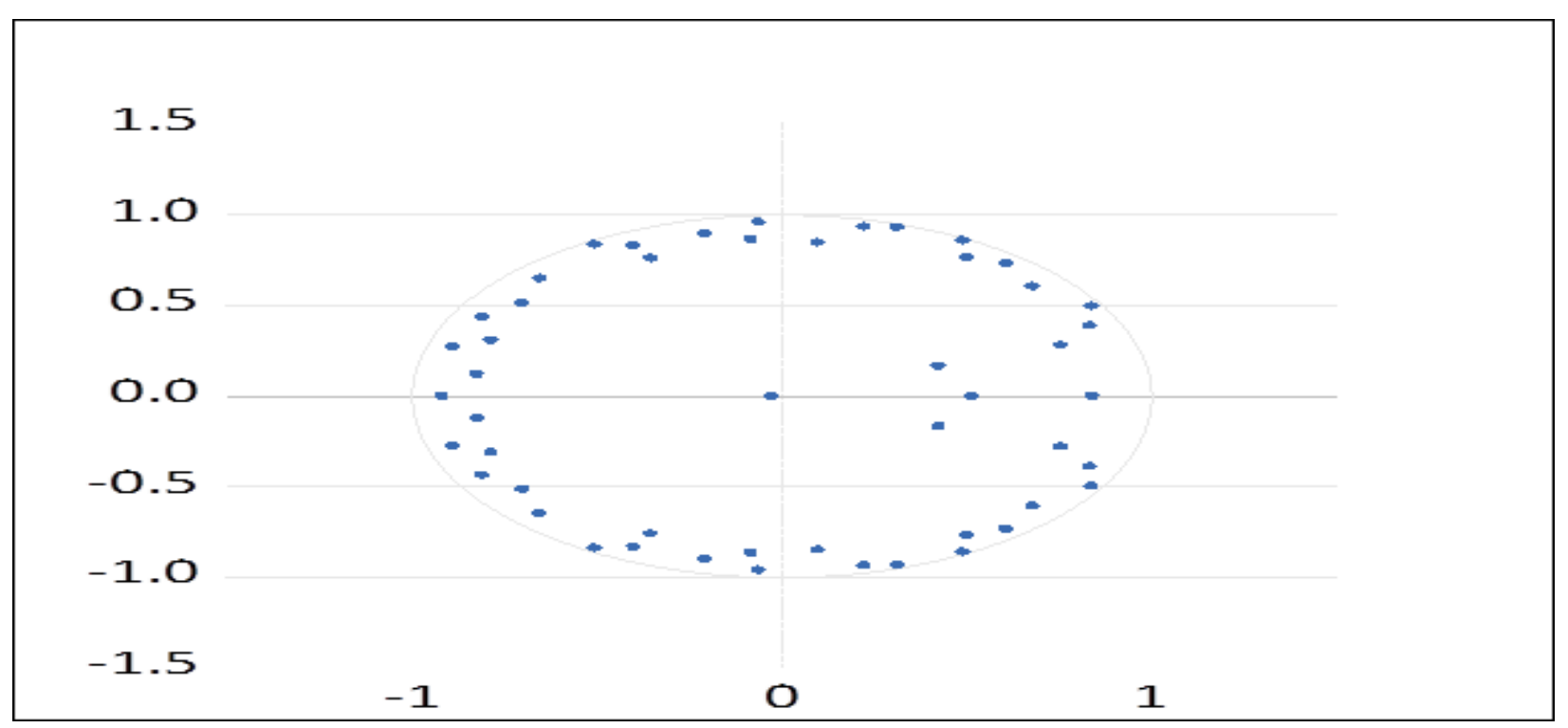

Table 1: Autocorrelation Test

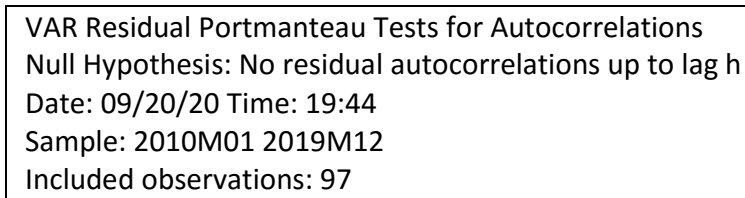

\begin{tabular}{|c|c|c|c|c|c|}
\hline Lags & Q-Stat & Prob.* & Adj Q-Stat & Prob.* & $\mathrm{df}$ \\
\hline 1 & 20.00810 & --- & 20.21652 & --- & --- \\
\hline 2 & 38.68864 & --- & 39.29034 & --- & --- \\
\hline 3 & 55.89475 & --- & 57.04558 & --- & --- \\
\hline 4 & 70.67277 & --- & 72.45921 & --- & --- \\
\hline 5 & 83.09612 & --- & 85.55774 & --- & --- \\
\hline 6 & 94.59774 & --- & 97.81771 & --- & --- \\
\hline 7 & 104.6226 & --- & 108.6223 & --- & --- \\
\hline 8 & 115.2428 & --- & 120.1971 & --- & --- \\
\hline 9 & 129.2152 & --- & 135.5985 & --- & --- \\
\hline 10 & 144.4006 & --- & 152.5293 & --- & --- \\
\hline 11 & 152.2732 & 0.0000 & 161.4089 & 0.0000 & 25 \\
\hline
\end{tabular}


Table 2: VAR Residual Normality Tests

\begin{tabular}{|c|c|c|c|c|}
\hline $\begin{array}{l}\text { VAR Residual Normality Tests } \\
\text { Orthogonalization: Residual Corr } \\
\text { Null Hypothesis: Residuals are m } \\
\text { Date: 09/20/20 Time: 19:44 } \\
\text { Sample: } 2010 \text { M01 2019M12 } \\
\text { Included observations: } 97\end{array}$ & & & & \\
\hline Component & Kurtosis & Chi-sq & $d f$ & Prob. \\
\hline 1 & 4.372834 & 0.395852 & 1 & 0.5292 \\
\hline 2 & 3.064305 & 0.008939 & 1 & 0.9247 \\
\hline 3 & 22.01000 & 1.314767 & 1 & 0.2515 \\
\hline 4 & 2.729873 & 0.082731 & 1 & 0.7736 \\
\hline 5 & 4.084571 & 1.886035 & 1 & 0.1696 \\
\hline Joint & & 3.688323 & 5 & 0.5951 \\
\hline \multicolumn{5}{|c|}{$\begin{array}{l}\text { *Approximate } p \text {-values do not account for coefficient } \\
\text { estimation }\end{array}$} \\
\hline
\end{tabular}

Table 3: Heteroskedasticity Test

\begin{tabular}{|l|l|l|l|}
\hline F-statistic & 1.672788 & Prob. F(10,86) & 0.1003 \\
\hline Obs*R-squared & 15.79517 & Prob. Chi-Square(10) & 0.1056 \\
\hline
\end{tabular}

\section{FINDINGS AND DISCUSSIONS}

According to the variance decomposition results of the variable number of firms opened; Apart from the variable's own effect, the most effective variable in the early periods is the exchange rate. However, after the 5th period, the effect of the inflation variable has increased. After the 10th period, the inflation variable became the most important variable. This result can be discussed in terms of profit expectations. Since the increase in inflation expectations will increase profitability expectations, it can be claimed that the number of companies opened has increased.

According to the results of impulse-response functions; In the first periods, exchange rate, interest rate and inflation shocks negatively affected the number of companies opened. In line with the results of the variance decomposition, inflation shocks increased in the following periods.

According to the variance decomposition results of the variable number of firms closed; After the 5th period, the exchange rate variable increased the number of firms that closed. In the following periods, the effects of the interest and inflation variables converged to the level of the effects of the exchange rate. High foreign exchange position of the companies in this case can be argued to Turkey caused the deficit.

According to the results of impulse-response functions, after the 5th period; Exchange, interest and inflation shocks increased the number of firms that closed. In parallel with the results of the variance decomposition, the variable of the number of firms closing showed the greatest response to exchange rate shocks. 
Figure 2: Variance Decomposition of Opening Firms

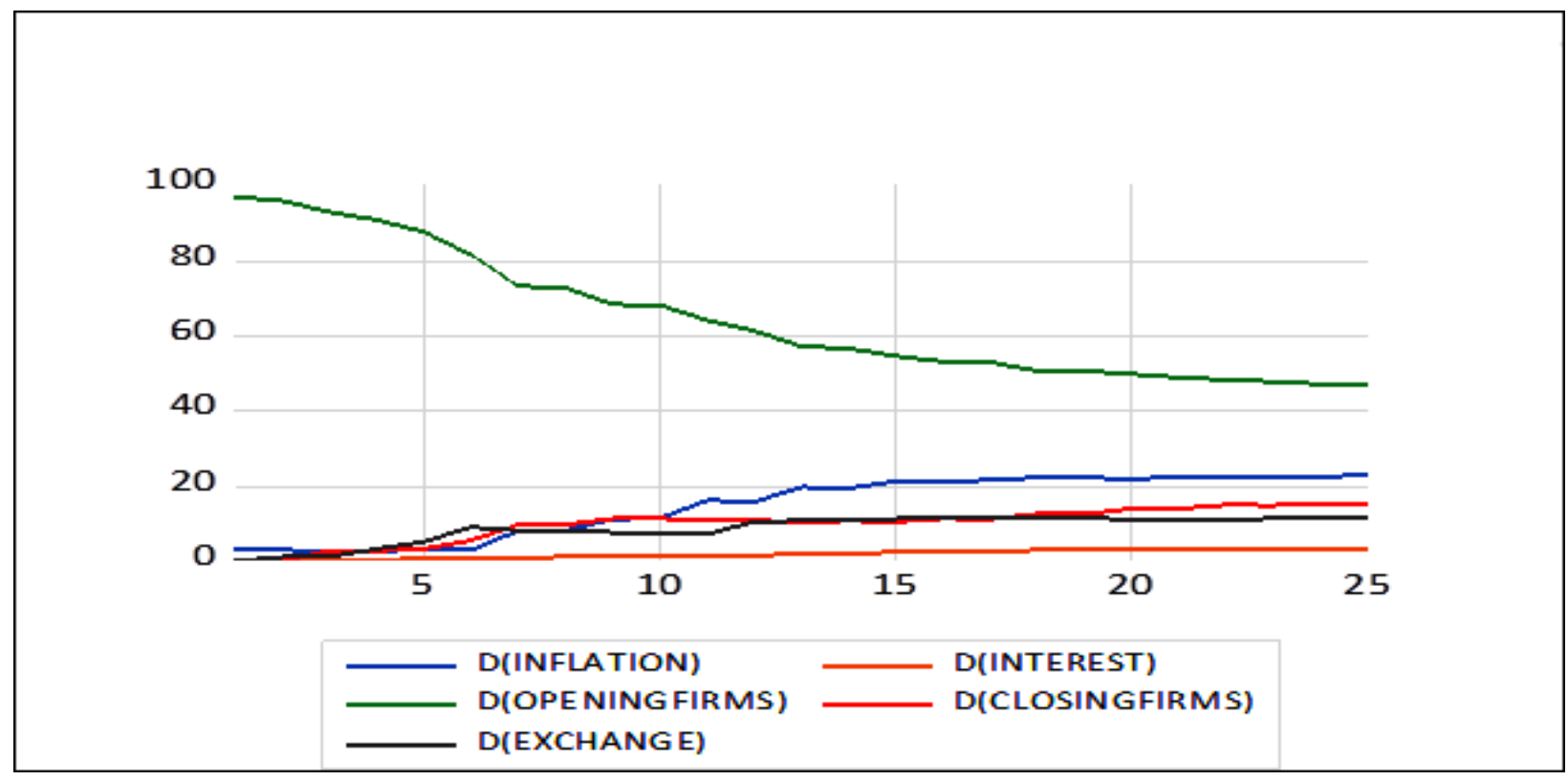

Table 4: Variance Decomposition of Opening Firms

\begin{tabular}{|c|c|c|c|c|c|c|}
\hline Period & S.E. & $\begin{array}{c}\text { D } \\
\text { (CLOSINGFIRMS) }\end{array}$ & $\begin{array}{c}\text { D } \\
\text { (EXCHANGE) }\end{array}$ & $\begin{array}{c}\text { D } \\
\text { (INTEREST) }\end{array}$ & $\begin{array}{c}\text { D } \\
\text { (INFLATION) }\end{array}$ & $\begin{array}{c}\text { D } \\
\text { (OPENINGFIRMS) }\end{array}$ \\
\hline 1 & 0.878293 & 2.373140 & 1.677448 & 1.120974 & 2.861869 & 91.96657 \\
\hline 2 & 0.890874 & 2.345543 & 3.052293 & 1.135526 & 2.864371 & 90.60227 \\
\hline 3 & 1.129382 & 1.697525 & 4.148334 & 0.844660 & 3.194744 & 90.11474 \\
\hline 4 & 1.151116 & 1.687111 & 6.452850 & 0.957391 & 3.131887 & 87.77076 \\
\hline 5 & 1.172186 & 2.075571 & 8.293122 & 0.940800 & 3.944979 & 84.74553 \\
\hline 6 & 1.215530 & 4.145431 & 11.94126 & 0.874924 & 3.989909 & 79.04848 \\
\hline 7 & 1.283139 & 6.885779 & 10.74798 & 2.187193 & 8.670079 & 71.50897 \\
\hline 8 & 1.293423 & 6.929575 & 10.67253 & 2.853209 & 8.532867 & 71.01182 \\
\hline 9 & 1.334501 & 7.963821 & 10.19900 & 4.210741 & 10.75604 & 66.87040 \\
\hline 10 & 1.344466 & 8.108023 & 10.05483 & 4.474203 & 10.79417 & 66.56877 \\
\hline 11 & 1.387455 & 7.685260 & 9.441981 & 5.957588 & 14.19759 & 62.71759 \\
\hline 12 & 1.419200 & 7.779396 & 12.22331 & 5.817410 & 13.96547 & 60.21441 \\
\hline 13 & 1.469766 & 7.253334 & 12.41676 & 5.653287 & 18.42869 & 56.24793 \\
\hline 14 & 1.479983 & 7.623636 & 12.55016 & 5.643442 & 18.17958 & 56.00319 \\
\hline 15 & 1.509262 & 7.353341 & 12.75638 & 5.452604 & 20.55332 & 53.88436 \\
\hline 16 & 1.537145 & 8.242200 & 13.50976 & 5.281180 & 20.39860 & 52.56826 \\
\hline 17 & 1.549045 & 8.137060 & 13.42312 & 5.355267 & 20.75247 & 52.33209 \\
\hline 18 & 1.584187 & 10.03671 & 13.21286 & 5.130564 & 21.57083 & 50.04904 \\
\hline 19 & 1.594126 & 10.28585 & 13.21508 & 5.067543 & 21.57449 & 49.85705 \\
\hline 20 & 1.618037 & 12.24754 & 12.84640 & 5.087856 & 21.09430 & 48.72391 \\
\hline 21 & 1.633434 & 12.40755 & 12.89562 & 4.997757 & 21.88939 & 47.80968 \\
\hline 22 & 1.648515 & 13.58675 & 12.82092 & 4.963359 & 21.56703 & 47.06194 \\
\hline 23 & 1.657301 & 13.44878 & 12.92620 & 4.933356 & 22.02208 & 46.66958 \\
\hline 24 & 1.668965 & 13.97963 & 12.87463 & 4.961772 & 22.16375 & 46.02021 \\
\hline 25 & 1.674645 & 13.99999 & 12.78966 & 5.164179 & 22.32587 & 45.72029 \\
\hline
\end{tabular}


Figure 3: Variance Decomposition of Closing Firms

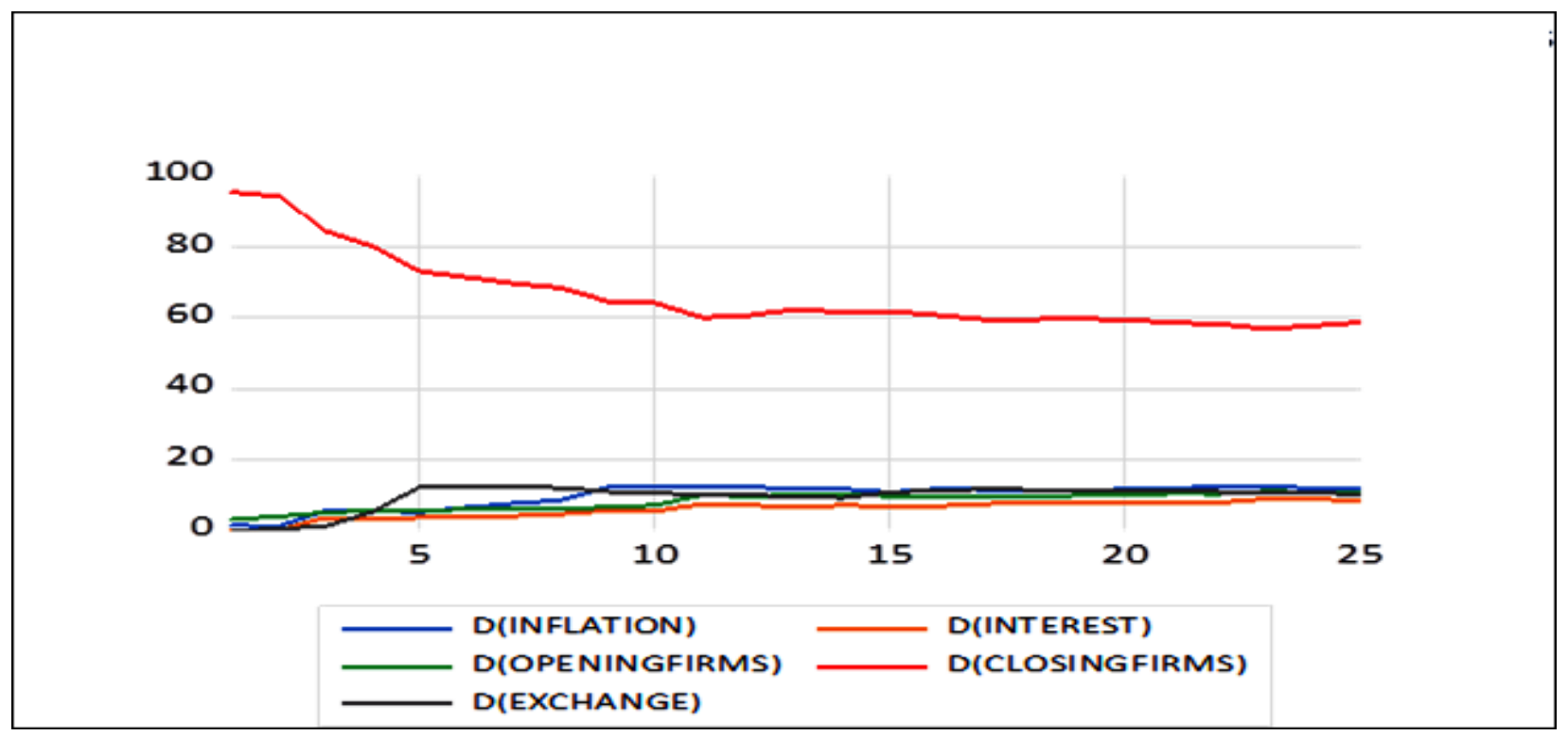

Table 5: Variance Decomposition of Closing Firms

\begin{tabular}{|c|c|c|c|c|c|c|}
\hline Period & S.E. & $\begin{array}{c}\text { D } \\
\text { (CLOSINGFIRMS) }\end{array}$ & $\begin{array}{c}\text { D } \\
\text { (EXCHANGE) }\end{array}$ & $\begin{array}{c}\text { D } \\
\text { (INTEREST) }\end{array}$ & $\begin{array}{c}\text { D } \\
\text { (INFLATION) }\end{array}$ & $\begin{array}{c}\text { D } \\
\text { (OPENINGFIRMS) }\end{array}$ \\
\hline 1 & 0.248918 & 100.0000 & 0.000000 & 0.000000 & 0.000000 & 0.000000 \\
\hline 2 & 0.263177 & 97.04670 & 0.663566 & 0.071047 & 0.067652 & 2.151036 \\
\hline 3 & 0.304342 & 90.28233 & 1.288803 & 1.015930 & 5.427578 & 1.985359 \\
\hline 4 & 0.314160 & 85.76496 & 5.487655 & 1.190616 & 5.468757 & 2.088013 \\
\hline 5 & 0.330179 & 77.90094 & 11.06634 & 2.595641 & 4.955547 & 3.481535 \\
\hline 6 & 0.335803 & 75.70243 & 10.90866 & 3.223078 & 5.958305 & 4.207517 \\
\hline 7 & 0.340370 & 73.69857 & 11.10951 & 4.395344 & 6.286053 & 4.510527 \\
\hline 8 & 0.346059 & 71.96571 & 10.91744 & 5.744385 & 6.629189 & 4.743275 \\
\hline 9 & 0.363043 & 68.06818 & 9.919904 & 5.241517 & 11.06853 & 5.701878 \\
\hline 10 & 0.369510 & 68.21772 & 9.621845 & 5.087175 & 11.03874 & 6.034526 \\
\hline 11 & 0.384822 & 64.06552 & 9.138384 & 5.446070 & 13.09796 & 8.252067 \\
\hline 12 & 0.394306 & 64.87288 & 9.370008 & 5.187947 & 12.67341 & 7.895762 \\
\hline 13 & 0.414686 & 66.59351 & 8.876103 & 4.894870 & 12.18811 & 7.447405 \\
\hline 14 & 0.421935 & 66.11674 & 8.660861 & 5.004701 & 12.65851 & 7.559183 \\
\hline 15 & 0.439355 & 66.18296 & 10.05681 & 5.032260 & 11.68801 & 7.039953 \\
\hline 16 & 0.443769 & 64.99177 & 10.43870 & 4.937016 & 12.72253 & 6.909985 \\
\hline 17 & 0.448859 & 63.82526 & 10.55766 & 5.840340 & 12.45845 & 7.318289 \\
\hline 18 & 0.453401 & 63.73158 & 10.55219 & 6.101902 & 12.30330 & 7.311026 \\
\hline 19 & 0.458294 & 64.17226 & 10.33754 & 6.064812 & 12.04347 & 7.381916 \\
\hline 20 & 0.460314 & 63.69194 & 10.24844 & 6.156969 & 12.46898 & 7.433678 \\
\hline 21 & 0.463780 & 62.82873 & 10.23288 & 6.105084 & 12.75265 & 8.080653 \\
\hline 22 & 0.466847 & 62.13926 & 10.10982 & 6.059537 & 13.65361 & 8.037777 \\
\hline 23 & 0.472309 & 60.84982 & 9.881767 & 6.948149 & 13.54425 & 8.776013 \\
\hline 24 & 0.477926 & 61.48688 & 9.658214 & 6.826163 & 13.43925 & 8.589501 \\
\hline 25 & 0.488000 & 62.76652 & 9.263584 & 6.739638 & 12.89357 & 8.336683 \\
\hline
\end{tabular}


Figure 4: Response of Opening Firms (One S.D)

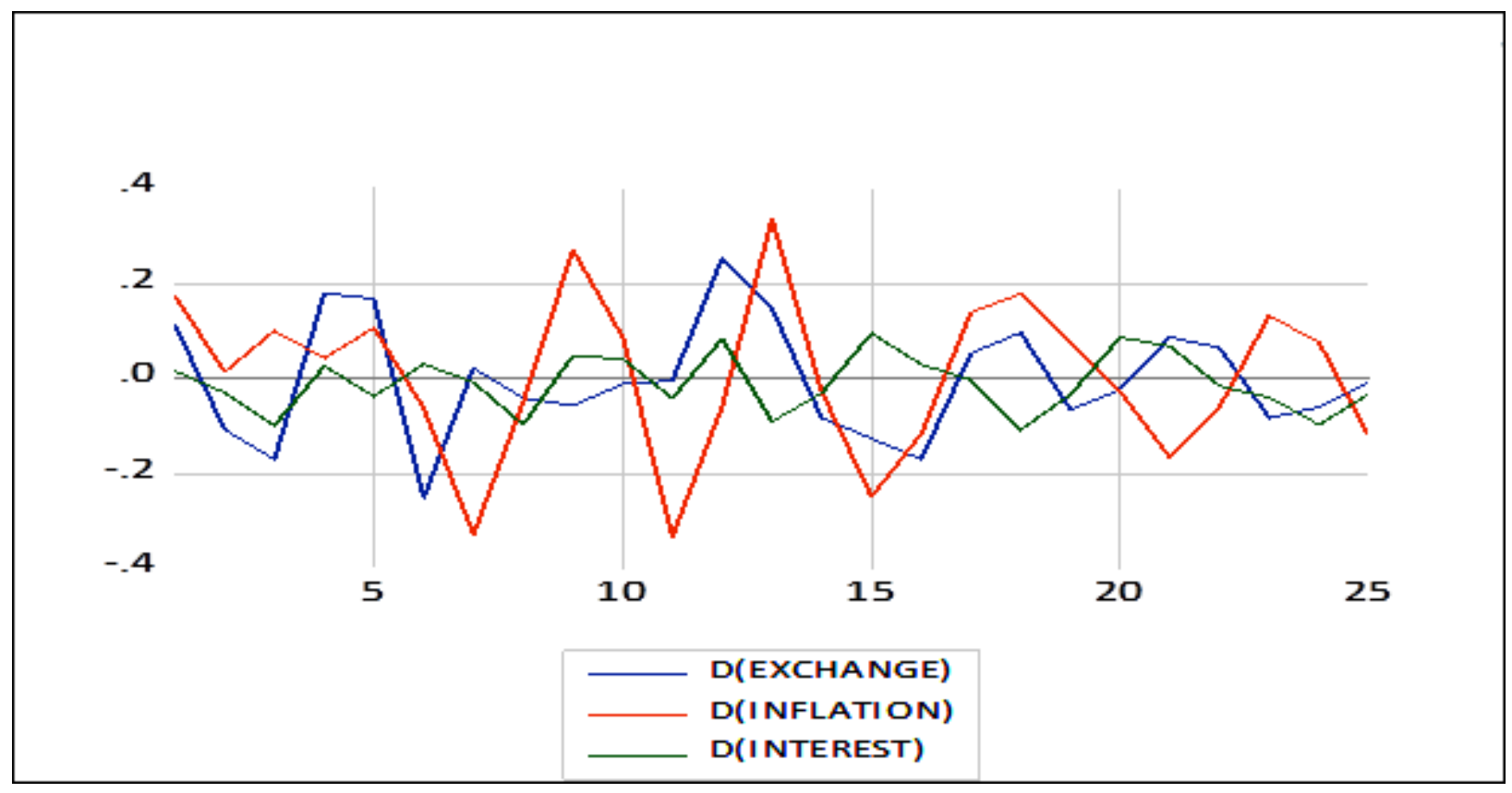

Figure 5: Response of Closing Firms (One S.D)

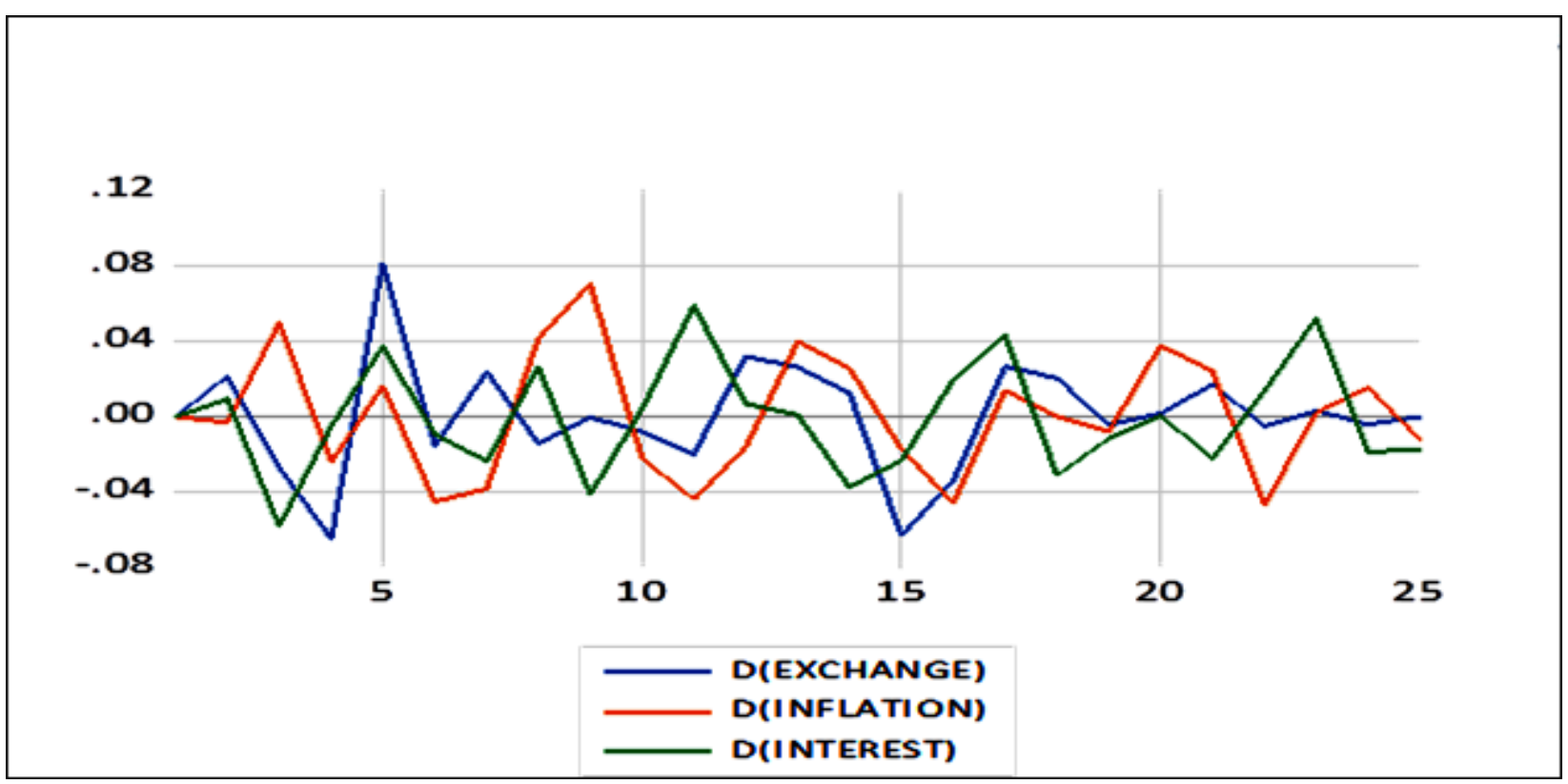

\section{CONCLUSION}

As a result of the low exchange rate-high interest rate policy in the Turkish economy, foreign exchange rates and inflation increases are generally realized through interest rate shocks through interest rate hike expectations (Kuzu, 2019). To summarize the results together with the theoretical framework, the number of firms that closing in Turkey is increasing because the shock waves in the exchange rates due to the high foreign exchange position deficits damage the equity structure of the firms. In addition, it can be argued that there is a negative correlation between the change in interest rates and the number of firms that opening, as the 
financing costs of firms are an important account item during the investment period. In order for the inflation variable to have a positive effect on number of opening firm through profit expectations, inflation needs to be in a downward trend. In short, while exchange rates are stable in a certain band range and inflation and interest rates fall together, net firm growth in Turkey increases.

\section{REFERENCES (use APA style for formatting and provide the full reference info)}

Aguilar, O.and Posada, R., (2019). Factors That Determine the Closure or Jeopardize the Continuity of a Micro and Small Enterprise. Organizations and Markets in Emerging Economies. 10. 78-91. 10.15388/omee.2019.10.00004.

Bakış O. and Kökkızıl, M., (2017). Betam Araştırma Notu, http://betam.bahcesehir.edu.tr/wp-content/uploads/2017/07/ArastirmaNotu214.pdf

Barışık, S. ve Kesikoğlu, F. (2006). -Türkiye'de Bütçe Açıklarının Makro Ekonomik Değişkenler Üzerine Etkisi (1987-2003 VAR, Etki-Tepki analizi, Varyans Ayrıştırması).|| Ankara Üniversitesi Siyasal Bilgiler Fakültesi Dergisi, 61(4).

Brooks, C. (2014). Introductory Econometrics For Finance (3rd edition), Cambridge.

Coleman, S., and Cotei, C., and Farhat, J.,;(2010), Factors Affecting Survival, Closure and MandA Exit for Small Businesses (November 1, 2010). Midwest Finance Association 2012 Annual Meetings Paper, Available at SSRN: https://ssrn.com/abstract=1768728 or http://dx.doi.org/10.2139/ssrn.1768728

D.A.Dickey and W.A. Fuller (1979): "Distribution of the Estimators for Autoregressive Time Series with a Unit Root", Journal of American Statistical Association, Vol:74.

Darnell, C. A., (1990), “Dictionary of Econometrics, England: Edward Elgar Publications”.

Egbunike, C. F., and Okerekeoti, C. U. (2018). Macroeconomic factors, firm characteristics and financial performance. Asian Journal of Accounting Research, 3(2), 142-168. https://doi.org/10.1108/ajar-09-2018-0029

Eliot, L. (2018), How serious is Turkey's lira crisis and what are the implications? Larry Elliott Economics editor https://www.theguardian.com/world/2018/aug/13/how-serious-is-turkeys-lira-crisis-and-what-are-the-implications.

Ertaş, F. and Çetin, A.,K. (2009). Türkiye'de Şirketleşme ve Ekonomik Değişkenlerle Olan Etkileşimi: 1995-2008. Muhasebe ve Finansman Dergisi. 43. 85-96.

Headd, B. Small Business Economics (2003) 21: 51. https://doi.org/10.1023/A:102443363.

Kearney, C. and Monadjemi, M. (1990). Fiscal Policy and Current Account Performance: International Evidence on the Twin Deficits, Journal of Macroeconomics. 12 (2): 197-21

Keating, John, (1990). Identifying VAR models under rational expectations, Journal of Monetary Economics, 25, issue 3, p. $453-476$.

Kerra Geldi H., Volatility Of The Turkish Lira After The Global Financial Crisis" Yeditepe Universty Department of Economics,Notes onEconomy,No: 2018-06, https://sbe.yeditepe.edu.tr/sites/default/files/u368/ekonomi-notlari-2018-6.pdf.

Kuzu, M. (2019), Döviz kuru, faiz oranı ve enflasyon çerçevesinde cari işlemler dengesinin yönetimi, Gazi üniversitesi Sosyal Bilimler Enstitüsü, Yayımlanmamış Doktora Tezi.

Lutkepohl, H. (2005), New Introduction to Multiple Time Series Analysis, Springer, Berlin. (L).

Metzger, G. (2008). Firm Closure, Financial Losses and the Consequences for an Entrepreneurial Restart. ZEW - Zentrum für Europaische Wirtschaftsforschung / Center for European Economic Research, ZEW Discussion Papers. 10.2139/ssrn.1314249.

Oyvat, C, (2018). "The End of Boom and the Political Economy of Turkey's crisis," Greenwich Papers in Political Economy 21403, University of Greenwich, Greenwich Political Economy Research Centre.

Özgen, F. B., and Güloğlu, B. (2004). "Türkiye'de iç Borçların iktisadi Etkilerinin VAR, Tekniği ile Analizi," METU Studies In Development, 1: $93-11$

Sims, C.,A. (1980) "Macroeconomics and Reality." Econometrica, vol. 48, no. 1, 1980, pp. 1-48. JSTOR, www.jstor.org/stable/1912017. Accessed 15 July 2020. 


\section{APPENDICES}

\section{Appendix 1: Unit Root Test}

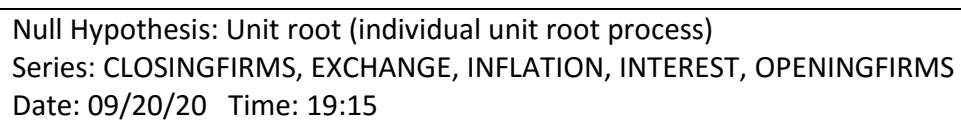

\begin{tabular}{|l|l|l|}
\hline Method & Statistic & Prob. $^{* *}$ \\
\hline ADF - Fisher Chi-square & 4.94635 & 0.8947 \\
\hline ADF - Choi Z-stat & 0.66797 & 0.7479 \\
\hline
\end{tabular}

** Probabilities for Fisher tests are computed using an asymptotic Chi

-square distribution. All other tests assume asymptotic normality. Intermediate ADF test results UNTITLED

\begin{tabular}{|l|l|l|l|l|}
\hline Series & Prob. & Lag & Max Lag & Obs \\
\hline CLOSINGFIRMS & 0.6765 & 12 & 12 & 107 \\
\hline EXCHANGE & 0.5454 & 5 & 11 & 107 \\
\hline INFLATION & 0.4952 & 2 & 12 & 117 \\
\hline INTEREST & 0.6631 & 1 & 12 & 118 \\
\hline OPENINGFIRMS & 0.6959 & 6 & 12 & 113 \\
\hline & & & & \\
\hline
\end{tabular}

Null Hypothesis: Unit root (individual unit root process)

Series: CLOSINGFIRMS, EXCHANGE, INFLATION, INTEREST, OPENINGFIRMS

Date: 09/20/20 Time: 19:16

Sample: 2010M01 2019M12

Exogenous variables: None

Automatic selection of maximum lags

Automatic lag length selection based on AIC: 0 to 12

Total number of observations: 561

Cross-sections included: 5

Method

ADF - Fisher Chi-square

ADF - Choi Z-stat

\begin{tabular}{|l|l|}
\hline Statistic & Prob.** $^{* *}$ \\
\hline 429.006 & 0.0000 \\
\hline-18.8773 & 0.0000 \\
\hline
\end{tabular}

** Probabilities for Fisher tests are computed using an asymptotic Chi

-square distribution. All other tests assume asymptotic normality. Intermediate ADF test results D(UNTITLED)

\begin{tabular}{|l|l|l|l|l|}
\hline Series & Prob. & Lag & Max Lag & Obs \\
\hline D(CLOSINGFIRMS) & 0.0007 & 12 & 12 & 106 \\
\hline D(EXCHANGE) & 0.0000 & 4 & 11 & 107 \\
\hline D(INFLATION) & 0.0000 & 1 & 12 & 117 \\
\hline D(INTEREST) & 0.0000 & 0 & 12 & 118 \\
\hline D(OPENINGFIRMS) & 0.0000 & 5 & 12 & 113 \\
\hline
\end{tabular}




\section{Appendix 2: VAR Lag Order Selection}

\begin{tabular}{|c|c|c|c|c|c|c|}
\hline \multicolumn{7}{|c|}{$\begin{array}{l}\text { VAR Lag Order Selection Criteria } \\
\text { Endogenous variables: D(INFLATION) D } \\
\text { Exogenous variables: C } \\
\text { Date: 09/20/20 Time: } 19: 43 \\
\text { Sample: } 2010 \mathrm{M} 01 \text { 2019M12 } \\
\text { Included observations: } 97\end{array}$} \\
\hline Lag & LogL & LR & FPE & AIC & SC & HQ \\
\hline 0 & -262.5183 & NA & 0.000171 & 5.515840 & $5.648557^{*}$ & $5.569505^{*}$ \\
\hline 1 & -234.1438 & 53.23863 & 0.000160 & 5.446264 & 6.242567 & 5.768250 \\
\hline 2 & -187.8093 & 82.16018 & 0.000103 & 5.006377 & 6.466265 & 5.596684 \\
\hline 3 & -164.0164 & 39.73655 & 0.000107 & 5.031267 & 7.154740 & 5.889895 \\
\hline 4 & -127.5367 & 57.16415* & $8.61 \mathrm{e}-05^{*}$ & 4.794571 & 7.581629 & 5.921520 \\
\hline 5 & -111.4788 & 23.50741 & 0.000107 & 4.978944 & 8.429588 & 6.374215 \\
\hline 6 & -90.66710 & 28.32106 & 0.000122 & 5.065301 & 9.179530 & 6.728894 \\
\hline 7 & -72.10643 & 23.34435 & 0.000150 & 5.198071 & 9.975885 & 7.129985 \\
\hline 8 & -46.09815 & 30.03018 & 0.000162 & 5.177281 & 10.61868 & 7.377517 \\
\hline 9 & -12.38867 & 35.44708 & 0.000154 & 4.997705 & 11.10269 & 7.466262 \\
\hline 10 & 26.23060 & 36.62859 & 0.000138 & 4.716895* & 11.48546 & 7.453773 \\
\hline $\begin{array}{l}* \text { inc } \\
\text { LR: } s \\
\text { FPE: } \\
\text { AIC: } \\
\text { SC: } \\
\text { HQ: }\end{array}$ & $\begin{array}{l}\text { tes lag orde } \\
\text { dential modi } \\
\text { al predictior } \\
\text { ike informa } \\
\text { warz inform } \\
\text { inan-Quinn }\end{array}$ & $\begin{array}{l}\text { ed by the crite } \\
\text { test statistic }(\epsilon \\
\text { terion } \\
\text { iterion } \\
\text { ation criterion }\end{array}$ & test at $5 \%$ lev & & & \\
\hline
\end{tabular}

\section{Appendix 3: AR Roots of Characteristic Polynomial}

\section{Roots of Characteristic Polynomial}

Endogenous variables: D(INFLATION), D(INTEREST) D(OPENINGFIRMS), D(CLOSINGFIRMS) D(EXCHANGE)

Exogenous variables: $\mathrm{C}$

Lag specification: 110

Date: 09/20/20 Time: 19:43

\begin{tabular}{|c|c|}
\hline Root & Modulus \\
\hline $0.490564+0.858196 i$ & 0.988511 \\
\hline $0.490564-0.858196 i$ & 0.988511 \\
\hline $0.312886+0.932265 i$ & 0.983370 \\
\hline $0.312886-0.932265 i$ & 0.983370 \\
\hline$-0.504515-0.836431 i$ & 0.976807 \\
\hline$-0.504515+0.836431 i$ & 0.976807 \\
\hline $0.838935-0.496883 i$ & 0.975040 \\
\hline $0.838935+0.496883 i$ & 0.975040 \\
\hline$-0.060968+0.959414 i$ & 0.961349 \\
\hline$-0.060968-0.959414 i$ & 0.961349 \\
\hline $0.222061+0.933776 i$ & 0.959817 \\
\hline $0.222061-0.933776 i$ & 0.959817 \\
\hline $0.606518-0.732014 i$ & 0.950636 \\
\hline $0.606518+0.732014 i$ & 0.950636 \\
\hline$-0.888432+0.272223 i$ & 0.929202 \\
\hline$-0.888432-0.272223 i$ & 0.929202 \\
\hline$-0.398571+0.830846 i$ & 0.921501 \\
\hline
\end{tabular}




\begin{tabular}{|c|c|}
\hline$-0.398571-0.830846 i$ & 0.921501 \\
\hline $0.834542+0.388858 i$ & 0.920690 \\
\hline $0.834542-0.388858 i$ & 0.920690 \\
\hline$-0.653151-0.648668 i$ & 0.920530 \\
\hline$-0.653151+0.648668 i$ & 0.920530 \\
\hline$-0.205217+0.896543 i$ & 0.919730 \\
\hline$-0.205217-0.896543 \mathrm{i}$ & 0.919730 \\
\hline$-0.809707-0.435267 i$ & 0.919283 \\
\hline$-0.809707+0.435267 i$ & 0.919283 \\
\hline-0.917793 & 0.917793 \\
\hline $0.501310+0.765295 i$ & 0.914870 \\
\hline $0.501310-0.765295 i$ & 0.914870 \\
\hline $0.679437+0.605606 i$ & 0.910161 \\
\hline $0.679437-0.605606 i$ & 0.910161 \\
\hline$-0.082369-0.865207 i$ & 0.869119 \\
\hline$-0.082369+0.865207 i$ & 0.869119 \\
\hline$-0.700673-0.511818 \mathrm{i}$ & 0.867698 \\
\hline$-0.700673+0.511818 i$ & 0.867698 \\
\hline $0.099577+0.847329 i$ & 0.853160 \\
\hline $0.099577-0.847329 i$ & 0.853160 \\
\hline$-0.785160-0.308177 i$ & 0.843474 \\
\hline$-0.785160+0.308177 i$ & 0.843474 \\
\hline 0.839300 & 0.839300 \\
\hline$-0.353491-0.760402 i$ & 0.838551 \\
\hline$-0.353491+0.760402 i$ & 0.838551 \\
\hline$-0.823170-0.121062 i$ & 0.832024 \\
\hline$-0.823170+0.121062 i$ & 0.832024 \\
\hline $0.755779-0.279684 i$ & 0.805869 \\
\hline $0.755779+0.279684 i$ & 0.805869 \\
\hline 0.516549 & 0.516549 \\
\hline $0.425359+0.165611 \mathrm{i}$ & 0.456462 \\
\hline $0.425359-0.165611 i$ & 0.456462 \\
\hline-0.024918 & 0.024918 \\
\hline \multicolumn{2}{|c|}{$\begin{array}{l}\text { No root lies outside the unit circle. } \\
\text { VAR satisfies the stability condition. }\end{array}$} \\
\hline
\end{tabular}

